\title{
Biological parameters and fertility life table of Aphis forbesi Weed, 1889 (Hemiptera: Aphididae) on strawberry
}

\author{
E. S. Araujo * , A. Benatto ${ }^{b}$, A. F. Mógor ${ }^{c}$, S. C. Penteado and M. A. C. Zawadneak $^{b}$ \\ aPrograma de Pós-graduação em Agronomia, Produção Vegetal, Departamento de Fitotecnia e Fitossanitarismo, \\ Universidade Federal do Paraná - UFPR, Rua dos Funcionários, 1540, CEP 80035-050, Curitiba, PR, Brazil \\ bLaboratório de Entomologia Prof. Ângelo Moreira da Costa Lima, Departamento de Patologia Básica, \\ Universidade Federal do Paraná - UFPR, Jardim das Américas, CEP 81531-980, Curitiba, PR, Brazil \\ 'Departamento de Fitotecnia e Fitossanitarismo, Universidade Federal do Paraná - UFPR, \\ Rua dos Funcionários, 1540, CEP 80035-050, Curitiba, PR, Brazil \\ ${ }^{d}$ Entomologia, Embrapa Florestas, CP 319, CEP 83411-000, Colombo, PR, Brazil \\ *e-mail: emiagro@yahoo.com.br
}

Received: March 24, 2015 - Accepted: September 1, 2015 - Distributed: November 30, 2016

\begin{abstract}
This study provides the first contribution of the biology and life table of Aphis forbesi Weed, 1889 (Hemiptera: Aphididae), an important strawberry pest throughout the world. This species lives in the crown and leaf petioles of the plant. It is difficulty to rear this species in laboratory due to protocooperation with ants observed only in the field. We studied the life cycle of $A$. forbesi on the leaves of the Albion strawberry cultivar at $25 \pm 2{ }^{\circ} \mathrm{C}, 60 \pm 10 \%$ relative humidity, and a 12 -h photophase. The experiment was randomised with 100 replicates. The parameters of the fertility life table were calculated using TabVida. In the population studied, $25 \%$ and $46 \%$ had four and three instars, respectively. A mean of 1.43 nymphs per female per day was generated. The mean reproductive period was seven days and the mean longevity was 10 days. In every 11 days there is a generation of $A$. forbesi, where each female has the potential to generate between 6 to 9 individuals daily, increasing its population by 1.2 times. The average life cycle was 16.8 days. High viability observed in all instars and the resulting values of $\mathrm{R}_{0}, \mathrm{r}_{\mathrm{m}}$ and $\lambda$ suggest that $A$. forbesi has the capacity to increase their numbers in a short period of time, while generating high populations in strawberry crops, requiring differential management.
\end{abstract}

Keywords: Fragaria $\mathrm{x}$ ananassa, root aphid, biological cycle, fertility life table.

\section{Parâmetros biológicos e tabela de vida de fertilidade de Aphis forbesi Weed, 1889 (Hemiptera: Aphididae) em morangueiro}

\section{Resumo}

Este trabalho apresenta a primeira contribuição ao estudo de biologia e tabela de vida de fertilidade de Aphis forbesi, Weed, 1889 (Hemiptera: Aphididae), uma importante praga de morangueiro no mundo. Esta espécie se desenvolve na coroa e pecíolo do morangueiro. O desenvolvimento desta espécie em laboratório apresentou dificuldades, possivelmente devido à protocooperação com formigas, observada em campo durante coletas. O ciclo de vida de $A$. forbesi foi estudado em folhas de morangueiro cultivar 'Albion' a $25 \pm 2{ }^{\circ} \mathrm{C}, 60 \pm 10 \%$ umidade relativa, e fotofase de 12 horas. O experimento foi inteiramente casualizado com 100 repetições. Os parâmetros da tabela de vida de fertilidade foram calculados usando o software TabVida. Na população estudada observou-se que as ninfas apresentaram três e quatro instares, sendo 46 e $25 \%$ respectivamente, dos indivíduos que completaram o ciclo de vida. Foi gerada uma média de 1,43 ninfas/ fêmea/ dia. O período reprodutivo médio foi de 7 dias e a longevidade média 10 dias. A cada 11 dias ocorre uma geração de $A$. forbesi onde cada fêmea tem capacidade de gerar de 6 a 9 indivíduos aumentando em 1,2 vezes a população. O ciclo de vida de $A$. forbesi durou em média 16,8 dias. A alta viabilidade observada em todos os estádios, e os valores de $\mathrm{R}_{0}, \mathrm{r}_{\mathrm{m}}$ e $\lambda$ sugerem que $A$. forbesi tem a capacidade de aumentar seu número em um curto período de tempo, gerando altas populações no cultivo do morangueiro, exigindo manejo diferenciado.

Palavras-chave: Fragaria $\mathrm{x}$ ananassa, pulgão-da-raiz, ciclo biológico, tabela de vida e fertilidade. 


\section{Introduction}

The Aphis forbesi Weed, commonly known as the root aphid is native to North America (Blackman and Eastop, 2006), it is an aphid pest affecting strawberry crops (Passos et al., 2000; Cédola and Greco, 2010; Araujo et al., 2013; Bernardi et al., 2013; Zawadneak et al., 2014). A. forbesi is also reported as a vector of the strawberry crinkle virus (Babovic and Krczal, 1976). This aphid species is easily recognised because it forms colonies in the crown and petioles of strawberry plants (Bernardi et al., 2013; Zawadneak et al., 2014). It can also be associated with ants (Solenopsis sp. and Camponotus sp.) that spread the pests in the fields and protect their colonies with mounds of soil, making its control more difficult (Zawadneak et al., 2014).

Fertility life tables aid in understanding the population dynamics of a given species (Van Lenteren and Woets, 1988; Bellows Junior et al., 1992). The reasons underlying the growth of species that are considered pests are important factors in pest management because they help predicting future increases in a population (Guldemond et al., 1998). In the context, information from fertility life tables can aid in the applied biological control programmes by assessing the reproductive potential of pests and their natural enemies (Bellows Junior et al., 1992; Bernardi et al., 2013).

Although the root aphid is present in strawberry-producing regions, there is no information available about its biology, and this study is the first to contribute to this area. Laboratory rearing is not easily maintained, and likely the protocooperation field with ants in the field is an important factor for the successful establishment of colonies. This study investigated, for the first time, the life cycle of $A$. forbesi in leaves of strawberry and determined the parameters of population growth.

\section{Material and Methods}

\subsection{Establishment of A. forbesi colonies}

Aphids were obtained on 'Camino Real' cultivar strawberry plants of organic olericulture area in Pinhais Country, Paraná, Brazil $\left(25^{\circ} 25^{\prime} \mathrm{S}, 4^{\circ} 08^{\prime} \mathrm{W}, 930 \mathrm{~m}\right)$. The aphids were transferred to 'Albion' strawberry potted plants in a greenhouse, where their rearing was established.

\subsection{A. forbesi biological experiment}

The experiment was carried out in a climate-controlled room (at $25 \pm 2{ }^{\circ} \mathrm{C}$, with relative humidity of $60 \pm 10 \%$ and a $12 \mathrm{~h}$ photophase). Strawberry leaves were collected and placed in separated petri dishes $(1.3 \mathrm{~cm}$ high $\times 6.5 \mathrm{~cm}$ in diameter), which contained a background layer of $3 \mathrm{~mm}$ of water-agar (3\%) and nipagim (5\%), forming arenas. The tip of the leaf stem was capped with a small piece of wet cotton to avoid the leaf from drying out.

Three adult females of the strawberry root aphid were placed on each plate with the help of a slim paintbrush to allow reproduction. After 24 hours later, only one nymph was left per plate and the biological parameters were recorded. Everytime that the leaf showed any signs of senescence, it was changed by another. The duration and viability of the nymphal instars were determined daily by observations through a stereoscopic microscope, increasing at a power of $10 \mathrm{X}$, with the removal of exuviae. The nymphs obtained were counted to determine the daily and total production for each adult. Subsequently, the nymphs were removed, leaving just the adult.

The following biological parameters of $A$. forbesi were measured: survival during the nymphal stage, duration of each nymphal stage and total nymphal stage, adult, pre-reproductive, reproductive and post-reproductive periods, as well as longevity, total fertility and life cycle.

With the data obtained from $A$. forbesi biology were calculated the parameters used in the fertility life table, namely: $\left(r_{m}\right)$, defined as the maximum rate of increase achieved by a population with a fixed age distribution, over any timespan, under optimum space and feeding conditions, and without the influence of other factors (Andrewartha and Birch, 1954); (DT) indicates time needed for the population double in number (Coats, 1976; Rabinovich, 1978); (T), the mean interval between generations, is the average length of a generation; $\left(\mathrm{R}_{\mathrm{o}}\right)$, the net reproductive rate, is the total of female offspring produced per female during the reproduction period, that arrive to the next generation; $(\lambda)$, the finite rate of increase, is the number of times that the population multiplies in a unit time.

\subsection{Experimental design and analysis of data}

The fertility life table was developed and the parameters of population growth were estimated. The mean interval between generations $(T)$, the net reproductive rate $\left(R_{0}\right)$, the intrinsic rate of increase $\left(r_{m}\right)$, the finite rate of increase $(\lambda)$, and the time required for the population to double in number (DT) were calculated using the TabVida software, such as Penteado (2007) and Penteado et al. (2010) described. The experiment had a randomized design with 100 replicates.

\section{Results}

Of all the aphids evaluated, $25 \%$ completed the biological cycle in four nymphal instars, $46 \%$ in three instars and $29 \%$ did not complete the cycle.

The nymphal stage took between 6.5 and 7.2 days, respectively in three or four instars (Table 1).

The mean pre-reproductive period of the strawberry root aphid was 2.0 and 2.5 days for the aphids with three and four instars, respectively. The length of the reproductive period ranged from 6.6 to nine days, with a mean of 5.6 and 8.2 days for the aphids with four and three instars, respectively. The lengths of the post-reproductive period were 1.9 and 2.1 days for the aphids with four and three instars, respectively.

The mean longevity values of the aphids with four and three instars were 8.4 and 11.6 days, respectively; with mean biological cycle times of 15.6 and 18.11 days. The aphids with three and four instars produced 1.4 and 1.5 female nymphs per day, respectively, with the total number of nymphs per female being 11.50 and 8.23 (Table 1). The viability of each instar was high, exceeding $90 \%$. 
Table 1. Biological parameters (mean \pm standard error) of Aphis forbesi fed on strawberry leaves (Fragaria $\times$ ananassa 'Albion') at $25 \pm 2{ }^{\circ} \mathrm{C}, 60 \pm 10 \% \mathrm{UR}, 12$-h photoperiod.

\begin{tabular}{|c|c|c|c|c|c|c|c|c|c|}
\hline \multirow{2}{*}{ Biological parameters (days) } & \multicolumn{3}{|c|}{ With 3 instars* } & \multicolumn{3}{|c|}{ With 4 instars** } & \multicolumn{3}{|c|}{ Viability (\%) } \\
\hline & Mean & \pm & SE & Mean & \pm & SE & Mean & \pm & SE \\
\hline First instar & 1.8 & \pm & 0.1 & 1.1 & \pm & 0.1 & 99 & \pm & 1.81 \\
\hline Second instar & 2.3 & \pm & 0.1 & 1.9 & \pm & 0.3 & 96 & \pm & 6.10 \\
\hline Third instar & 2.4 & \pm & 0.1 & 2.2 & \pm & 0.2 & 95 & \pm & 7.62 \\
\hline Fourth instar & - & & & 2.0 & \pm & 0.2 & 94 & \pm & 8.57 \\
\hline Nymphal stage & 6.5 & \pm & 0.2 & 7.2 & \pm & 0.4 & 96 & \pm & 1.50 \\
\hline Pre-reproductive period & 2.0 & \pm & 0.2 & 2.5 & \pm & 0.4 & & & \\
\hline Reproductive period & 8.2 & \pm & 0.8 & 5.6 & \pm & 1 & & & \\
\hline Post-reprodutive period & 2.1 & \pm & 0.3 & 1.9 & \pm & 0.3 & & & \\
\hline Longevity & 11.6 & \pm & 0.9 & 8.4 & \pm & 0.8 & & & \\
\hline Total nymphs/female (n) & 11.5 & \pm & 1.2 & 8.2 & \pm & 1.7 & & & \\
\hline Nymphs/female/day (n) & 1.4 & \pm & 0.1 & 1.5 & \pm & 0.3 & & & \\
\hline Biological cycle (days) & 18.1 & \pm & 0.9 & 15.6 & \pm & 0.8 & & & \\
\hline
\end{tabular}

$*_{\mathrm{n}}=46$ to 3 instars. $* *_{\mathrm{n}}=25$ to 4 instars.

The highest percentage of $A$. forbesi survival occurred in the first instar (99\%), gradually decreasing through the fourth instar (Table 1).

The mean interval between generations $(\mathrm{T})$ was, on average, 11.3 and 11.81 days, and the net reproduction rate $\left(\mathrm{R}_{0}\right)$ was 5.81 and 9.12 for aphids that had four and three instars, respectively (Table 2 ).

The intrinsic rate of increase $\left(r_{\mathrm{m}}\right)$ values for $A$. forbesi with four and three instars was 0.1557 and 0.1872 , respectively. The aphids with four and three instars had a finite rate of increase $(\lambda)$ values of 1.1685 and 1.2059 , respectively.

The time needed for the population to duplicate in number (DT) for the aphids with three and four instars were 3.70 and 4.45 days, respectively.

\section{Discussion}

It was observed in the field that this species develops on the petioles and roots of strawberries, and can coexist with

C. fragaefolli colonies in the same plant. But, the aphid $C$. fragaefolli usually occurs on new shoots, in the crown, and close to the veins on the undersides of leaflets (Bernardi et al., 2012; Rondon and Cantliffe, 2015). Both are species associated with strawberry crops and could damage them (Bernardi et al., 2012). Since there is no information available about $A$. forbesi biology in strawberries, this discussion will be based primarily on data obtained for C. fragaefolli.

A. forbesi was able to complete the biological cycle on strawberries leaves, exhibiting three and four nymphal instars, although most exhibited three, which is probably the norm. These results are different from the results of Dixon (1987) and Minks and Harrewijn (1987), who reported that aphids generally undergo four nymphal instars, although part of the population will only undergo three (Kairo and Murphy, 1999). Bernardi et al. (2012) observed four
Table 2. Parameters of population growth for Aphis forbesi fed at strawberry leaves (Fragaria $\times$ ananassa 'Albion') $\left(25 \pm 2{ }^{\circ} \mathrm{C}, 60 \pm 10 \% \mathrm{UR}, 12\right.$-h photoperiod).

\begin{tabular}{lll}
\hline \multicolumn{1}{c}{ Parameters } & $\begin{array}{c}\text { Three } \\
\text { nymphal } \\
\text { instars }\end{array}$ & $\begin{array}{c}\text { Four } \\
\text { nymphal } \\
\text { instars }\end{array}$ \\
\hline $\begin{array}{l}\text { Time between each } \\
\text { generation }(\mathrm{T})\end{array}$ & 11.81 & 11.3 \\
Net reproduction rate $\left(\mathrm{R}_{\mathrm{o}}\right)$ & 9.12 & 5.81 \\
$\begin{array}{l}\text { Intrinsic rate of increase }\left(\mathrm{r}_{\mathrm{m}}\right) \\
\text { Finite rate of increase }(\Lambda)\end{array}$ & 0.1872 & 0.1557 \\
$\begin{array}{l}\text { Time for the population } \\
\text { double in number }(\mathrm{TD})\end{array}$ & 1.21 & 1.17 \\
\hline
\end{tabular}

nymphal instars for C. fragaefolii on strawberry, however, Chagas Filho et al. (2005) and Cédola and Greco (2010) reported the existence of a fifth instar. That is, although the most common is four instars for most aphids, it is found that variations can occur in quantities of the instars.

A. forbesi completed the nymphal stage in shorter time than observed by Bernardi et al. (2012) which reported that the duration of the nymphal phase of $C$. fragaefolli ranged from 8.67 to 11.12 days when seven different strawberry cultivars were analysed in similar conditions of this experiment. In cultivar Albion, it was observed a nymphal stage of 9.74 days to $C$. fragaefolli.

The mean pre-reproductive period of the $A$. forbesi was shorter than the pre-reproductive period of the C. fragaefolli that fed on cultivar Albion, which was 7.43 days (Bernardi et al., 2012). The reproductive period and, consequently, the production of offspring, is an indication of acceptance of the plant as an ideal host for insect development (Minks and Harrewijn, 1987). This could mean that $A$. forbesi is well adapted in strawberry plant. 
The $A$. forbesi viability of each instar was high, gradually decreasing until the fourth instar. Bernardi et al., (2012), observed a similar pattern to $C$. fragaefolli, the highest percentage of survival occurred in the first instar (94\%), and gradually decreasing through the fourth instar (71\%). Although the pattern was similar to $A$. forbesi, all instars had a higher percentage of survival when compared to result of C. fragaefolli.

The length of the reproductive period of the $A$. forbesi was shorter than the one observed in the $C$. fragaefolli by Bernardi et al., (2012) who observed a reproductive period in the $C$. fragaefolli, varying from 16.84 to 18.41 days; in the cultivar Albion these authors observed a period of 18.07 days. Cédola and Greco (2010) observed 11.8 days in the reproductive period of the $C$. fragaefolli.

Bernardi et al. (2012) found a cycle life of 17.17 days for $C$. fragaefolli in the cultivar Albion. This result was similar to $A$. forbesi. The same researchers observed that the aphids kept in cultivars Albion showed low daily nymphs by female per day (0.78) and the total fecundity was 14.09. Our results show that $A$. forbesi can reproduce more nymphs by female per day than $C$. fragaefolli, but the root aphid has a shorter life cycle so, the total fecundity was lower than that found to C. fragaefolli.

Every 11 days there is a new generation of $A$. forbesi, where each female has the potential to generate between 6 to 9 individuals, increasing its population by 1.2 times. (T) value to $A$. forbesi was similar to results reported by Razmjou et al. (2006) (9.06 to 10.72 days), and Michelotto et al. (2004) (10 to 10.63 days) to Aphis gossypii Glover, 1877 (Hemiptera: Aphididae) and is much lower than those results observed for $C$. fragaefolli, that there is a new generation every 27 days, and each female has the potential to generate 10 individuals, increasing its population by 1,1 times Bernardi et al. (2012), suggesting the potential for growth of a colony of $A$. forbes $i$ with large number of generations in a year.

The time for the population double in number (TD) observed in the $A$. forbesi is shorter than (TD) observed by Benatto (2014) who observed in the $C$. fragaefolli 5.61 days in the cultivar Albion.

The intrinsic rate of increase $\left(r_{m}\right)$ relates to $\left(R_{0}\right)$ and (T), indicating the biotic potential of the species (Price, 1984; Traicevski and Ward, 2002; Penteado, 2007). The $\left(r_{\mathrm{m}}\right)$ values for $A$. forbesi were positive, to aphids that exhibited three and four instars, and biggest than the results of Bernardi et al. (2012) which found, for C. fragaefolii the value to $\left(r_{m}\right)$ of 0.0976 , it means that the birth rate exceeded the mortality rate, leading to population growth.

Coats (1976) stated that $\left(\mathrm{r}_{\mathrm{m}}\right)$ was the most important parameter obtained from a life table because it allowed comparisons of the potential increases of species. Based on this, we can understand that $A$. forbes $i$ could be better adapted in this strawberry cultivar than $C$. fragaefolli, because it has a higher value of $\left(\mathrm{r}_{\mathrm{m}}\right)$ and this means being more successfull than a species in one given environment (Penteado, 2007).
The high viability observed in all instars and the results obtained in the fertility life tables suggest that $A$. forbes $i$ has the capacity to increase its numbers in a short period of time, while generating high populations in strawberry crops, requiring differential management.

\section{Acknowledgements}

The authors wish to thank Conselho Nacional de Pesquisa $\mathrm{CNPq} / \mathrm{MAPA}$ and PROext MEC/SESu for their financial support and Bioagro Ltda for their strawberry seedlings.

\section{References}

ANDREWARTHA, H.G. and BIRCH, L.C., 1954. The innate capacity for increase in numbers. In: H.G. ANDREWARTHA, ed. The distribution and abundance of animals. Chicago: Birch University of Chicago Press, pp. 31-54.

ARAUJO, E.S., ZAWADNEAK, M.A.C., TAVARES, M.T., BENATTO, A. and MÓGOR, Á.F., 2013. Occurrence of Lysiphlebus testaceipes (Cresson, 1880) (Hymenoptera: Braconidae: Aphidiinae) parasitizing Aphis forbesi Weed, 1889 (Hemiptera: Aphididae) in the strawberries crop in the metropolitan Region of Curitiba, Parana, Brazil. Brazilian Journal of Biology $=$ Revista Brasileira de Biologia, vol. 73, no. 1, pp. 221-222. http://dx.doi.org/10.1590/ S1519-69842013000100024. PMid:23644805.

BABOVIC, M.V. and KRCZAL, H., 1976. Investigation of strawberry virus disease in Yugoslavia. Acta Horticulturae, vol. 66, pp. 66

BELLOWS JUNIOR, T.S., VAN DRIESCHE, R.G. and ELKINTON, J.S., 1992. Life-table construction and analysis in the evaluation of natural enemies. Annual Review of Entomology, vol. 37, no. 1, pp. 587-614. http://dx.doi.org/10.1146/annurev.en.37.010192.003103.

BENATTO, A., 2014. Dinâmica populacional de afídeos do morangueiro; parâmetros de crescimento e estudo de comportamento alimentar de Chaetosiphon fragaefolii por EPG (electrical penetration graphs). Curitiba: Universidade Federal do Paraná, 89 p. Master's dissertation in Vegetables Production.

BERNARDI, D., ARAUJO, E.S., ZAWADNEAK, M.A.C., BOTTON, M., MÓGOR, A.F. and GARCIA, M.S., 2013. Aphid species and population dynamics associated with strawberry. Neotropical Entomology, vol. 42, no. 6, pp. 628-633. http:// dx.doi.org/10.1007/s13744-013-0153-1.

BERNARDI, D., GARCIA, M.S., BOTTON, M. and NAVA, D.E., 2012. Biology and fertility life table of the green aphid Chaetosiphon fragaefolli on strawberry cultivars. Journal of Insect Science, vol. 12, no. 28, pp. 28. http://dx.doi.org/10.1673/031.012.2801. PMid:22958325.

BLACKMAN, R.L. and EASTOP, V.F., 2006. Aphids on the world's herbaceous plants and shrubs: hosts lists and keys. Chichester: John Wiley \& Sons.

CÉDOLA, C. and GRECO, N., 2010. Presence of the aphid, Chaetosiphon fragaefolii, on strawberry in Argentina. Journal of Insect Science, vol. 10, no. 9, pp. 1-9. http://dx.doi. org/10.1673/031.010.0901. PMid:20569141.

CHAGAS FILHO, N.R., MICHELOTTO, M.D., SILVA, R.A. and BUSOLI, A.C., 2005. Desenvolvimento ninfal de Myzus persicae (Sulzer, 1776) (Hemiptera: Aphididae) sobre berinjela em diferentes temperaturas. Bragantia, vol. 4, pp. 257-262. 
COATS, S.A., 1976. Life cycle and behavior of Muscidifurax zaraptor (Hymenoptera: Pteromalidae). Annals of the Entomological Society of America, vol. 69, no. 4, pp. 772-780. http://dx.doi. org/10.1093/aesa/69.4.772.

DIXON, A.F.G., 1987. Parternogenetic reproduction and the rate of increase in aphids. In: A.K. MINKS, P. HARREWINJN. World crop pests. Aphids: Their biology, natural enemies and control. Amsterdam: Elsevier, chap. 4, pp. 269-287.

GULDEMOND, J.A., VAN DEN BRINK, W.J. and DEN BELDER, E., 1998. Methods of assessing population increase in aphids and the effect of growth stage of the host plant on population growth rates. Entomologia Experimentalis et Applicata, vol. 86, no. 2, pp. 163-173. http://dx.doi.org/10.1046/j.1570-7458.1998.00277.x.

KAIRO, M.T.K. and MURPHY, S.T., 1999. Temperature and plant nutrient effects on the development, survival and reproduction of Cinara sp. nov., an invasive pest of cypress trees in Africa. Entomologia Experimentalis et Applicata, vol. 92, no. 2, pp. 147-156. http://dx.doi.org/10.1046/j.1570-7458.1999.00534.x.

MICHELOTTO, M.D., SILVA, R.A. and BUSOLI, A.C., 2004. Tabela de vida para Aphis gossypii Glover, 1877 (Hemiptera: Aphididae) entre especies de malas hierbas. Boletin de Sanidad Vegetal, Plagas, vol. 30, pp. 211-217.

MINKS, A.K. and HARREWIJN, P., eds, 1987. World crop pests - Aphids: their biology, natural enemies and control. Amsterdam: Elsevier. $450 \mathrm{p}$.

PASSOS, F.A., BETTI, J.A. and TANAKA, M.A.S., 2000. Pragas do morangueiro. In: Manejo integrado de pragas $e$ doenças do morangueiro. Campinas: Secretaria de Agricultura e Abastecimento, pp. 55-61.

PENTEADO, S.R.C., 2007. Cinara atlantica (Wilson) (Hemiptera, Aphididae): um estudo de biologia e associações. Curitiba:
Universidade Federal do Paraná, 223 p. PhD Thesis in Biological Sciences - Entomology.

PENTEADO, S.R.C., OLIVEIRA, E.B. and LAZZARI, S.M.N., 2010 [viewed 29 May 2012]. Tab Vida: sistema computacional para cálculo de parâmetros biológicos e de crescimento populacional de afideos [online]. Brasília: EMBRAPA. Available from: http:// www.infoteca.cnptia.embrapa.br.

PRICE, P.W., 1984. Insect ecology. New York: John Willey.

RABINOVICH, J.E., 1978. Ecologia de poblaciones animales. Washington: Secretaria general de La organización de los Estados Americanos.

RAZMJOU, J., MOHARRAMIPOUR, S., FATHIPOUR, Y. and MIRHOSEINI, S.Z., 2006. Demographic parameters of cotton aphid, Aphis gossypii Glover (Homoptera: Aphididae) on five cotton cultivars. Insect Science and Its Application, vol. 13, no. 3, pp. 205-210. http://dx.doi.org/10.1111/j.1744-7917.2006.00083.x.

RONDON, S.I. and CANTLIFFE, D.J., 2015 [viewed 19 March 2015]. Biology and Control of the Strawberry Aphid, Chaetosiphon fragaefolli (Cockerell) (Homoptera: Aphididae) in Florida: HS1009 [online]. Florida: UF, pp. 1-4. Available from: http:// edis.ifas.ufl.edu/pdffiles/HS/HS25300.pdf

TRAICEVSKI, V. and WARD, S.A., 2002. Probing behaviour of Aphis craccivora Koch on host plants of different nutritional quality. European Journal of Entomology, vol. 27, pp. 213-219.

VAN LENTEREN, J.C. and WOETS, J., 1988. Biological and integrated pest control in greenhouses. Annual Review of Entomology, vol. 33, no. 1, pp. 239-269. http://dx.doi.org/10.1146/ annurev.en.33.010188.001323.

ZAWADNEAK, M., BOTTON, M., SCHUBER, J.M., SANTOS, B. and VIDAL, H.R., 2014. Pragas do morangueiro. In: M. ZAWADNEAK, J.M. SCHUBER, Á.F. MÓGOR, orgs. Como produzir morangos. Curitiba: UFPR, $280 \mathrm{p}$. 